\title{
Effect of Military Housing Condition on Housing Preference and Adequacy in Shadawanka Barrack Bauchi, Bauchi State, Nigeria
}

\author{
Oyeleke, Oyediran Olufemi ${ }^{1}$, Bala Ishiyaku ${ }^{2}$, Muhammad Maryam Salihu ${ }^{3}$, Sakariyau Jamiu Kayode ${ }^{4}$ \\ ${ }^{1}$ Department of Estate Management and Valuation, Federal Polytechnic Nassarawa, Nassarawa State, Nigeria \\ ${ }^{2,3,4}$ Department of Estate Management and Valuation, Faculty of Environmental Technology, Abubakar Tafawa Balewa \\ University, Bauchi. Nigeria
}

\begin{abstract}
The research sought to analyze military housing provision and Soldiers' housing preferences at shadawanka barrack Bauchi, with the goal of meeting the military personnel's housing demands in the study region. The study collected data using a quantitative technique and survey strategy using a descriptive and exploratory research design and a questionnaire instrument. The study's population consisted of military personnel, with a sample frame of 248 dwellings, assuming one personnel per house. A sample size of 160 people was chosen. The questionnaire on a five-point Likert scale was self-administered. According to the findings, the factors with the greatest and fair conditions are security, wall condition, floor condition, and finishing, while the variables with the lowest and lowest condition rating are sewage and road networks within the barrack. The barrack's general or average level of housing conditions was rated fair. Water supply and security are the variables with the highest levels of adequacy, whereas drainage and road networks have the lowest levels of adequacy and reaction. The general degree of appropriateness of the barracks' residences was rated unsatisfactory. The quality of the floor, the walls, and the number of bedrooms have moderate levels of satisfaction, whereas solid waste disposal and sewage have low levels of satisfaction. The most common source of unhappiness is the insufficiency of housing provision, which has the highest standardized Beta coefficient of 0.285 . The study recommended that the sewerage and solid waste disposal systems be improved. The service can be contracted out. Internal road networks and drainage systems within the barracks should be restored, and new ones created to give proper accessibility. There is a need for new dwellings to be built in order to relieve overcrowding in most homes. Because military personnel are dissatisfied with their housing owing to inadequacies, it is recommended that sufficient housing based on the demands of the soldiers be considered.
\end{abstract}

Keywords: Housing, Military housing provision, Soldiers Housing Preference, shadawanka barrack, Bauchi.

\section{INTRODUCTION}

$\mathrm{H}$ ousing was recognized as an element of health and quality of life and was a pillar of satisfaction for the individual (Kayode, Muhammad, \& Bello, 2021). Housing is one of humanity's three basic need. Its performance should meet both technical and general user standards. Home has a huge impact on people's lives as well as the lives of the country; hence, the role it plays in delivering human convenience via nature and society is critical (Musa, Bello, \& Kayode, 2021). Affordability is concerned with ensuring that particular housing requirements or other demands are provided at a cost or rent that does not place an undue financial strain on households (Sakariyau, Uwaezuoke, Olaoye \& Sani, 2021). Housing contentment is influenced by residents' perceptions of their neighborhood and living situations. This reflects a low degree of dissatisfaction and a high level of agreement between planned and actual circumstances, as well as renters' everyday housing expectations being met (Alabi, Kayode, Misbahu, \& Olaifa, 2021).

The number of housing units that must be built or maintained to keep the housing situation stable within the required level is referred to as the residential need. The strategies of development and urban renewal or replacement of residential areas are used to achieve this stability (Al-Habees, 2012). Demographic dynamics such as migration rates, population age structures, and household headship rates are examples of housing requirement drivers. Economic considerations, on the other hand, are important - both directly and indirectly - in terms of their effect on demographic outcomes such as household formation. General housing features include typical monthly housing expenses, unit kinds, locations, size, and condition, all of which impact housing affordability. This means that the household should be able to cover the immediate expenditures of the dwelling unit without sacrificing other important necessities (Kurraz \& Ziara, 2007).

During the time of military rule, which lasted from the late 1960s through the late 1990s, the country was subjected to a bombardment of unsuccessful attempts to address the housing problem. As a result, the civilian administration that took over in the late 1990s inherited a serious problem of inadequate housing as a result of many years of neglect, an underdeveloped housing finance system, a limited supply of long-term funds, a high interest rate on mortgages, high land and building material costs, and poor planning and 
implementation of housing policies and programs. administrative bottlenecks that make processing and obtaining approval of construction designs, Certificates of Occupancy, and other essential government licenses onerous, and unrelenting corruption in the allotment of government lands under the Land Use Act, Cap.202 LFN 1990 (Akomolede, 2007). The problem is further compounded by the high incidence of corruption in all other relevant sectors of the Nigerian economy and the lack of adequate political will by the government to deal decisively with the housing problem. There is also the problem of conflict of objectives among actors and stakeholders in the housing industry, namely: the funding institutions and the developers on one side and the consumers of housing on the other side. Several studies dealt with the housing needs issue. According to the UN Shelter Sector (2011), a total of 71,234 housing units are needed in Gaza by the end of 2011 to meet current population demands. This comprises 67,151 units required after June 2007 and a total shortfall of 4,083 units prior to 2007. According to the findings, natural population increase accounts for around 79 percent of housing demands. Approximately 9\% are the result of home demolition during and before the 2008/2009 "Cast Lead" military campaign. Tan (2012) investigates the housing requirements and preferences of first-time purchasers in Kuala Lumpur, with a focus on particular residence qualities such as the number of bathrooms, bedrooms, living spaces, and kitchens, among others. According to the findings of the survey, the number of bedrooms is frequently given top priority. The Study of Sean and Hong (2014) emphasized that in Western nations, the number of rooms or bathrooms in a house is a highly important component that is mainly examined by households when making home-ownership options According to prior research conducted by several authors, none of the previous studies explored military housing demands. As a result, this research will fill the gap by investigating military housing demands for efficient and effective provision at Shadawanka barrack Bauchi. The Research Objectives are:

1. To assess the status of the dwellings given at Shadawanka Barrack in Bauchi State.

2. To assess the sufficiency of the dwellings available in the study area.

3. Determine the optimal housing options for military personnel in the study area.

4. To examine the impact of home condition on desired housing and appropriateness in the research region.

\section{LITERATURE REVIEW}

\subsection{Military Barrack}

A high-quality barrack creates a one-of-a-kind atmosphere in which soldiers/sailors reside and perform their duties. Soldiers/sailors at Nigerian military establishments are frequently housed in residential buildings known as "barracks," which are proportionally split into measured living quarters and usually on very discounted rent. Generally, the military authorities provide electricity and water. A Naval Barrack is a controlled living environment that includes shared facilities and basic service amenities for sailors and troops who utilize it. It is often developed and owned by military institutions, provides for low-cost charged rooms, and is managed to house soldiers/sailors. This kind of dwelling is also known as a sailors'/soldiers' hall of residence, soldier accomodation, soldiers' barracks, or a 'boarding house.' Furthermore, on-barracks soldier housing meets the accommodation needs of soldiers/sailors while they pursue academics, housing, and social actions throughout their military careers (Kelly, 2020). Cohen (2017) It was also noted that for soldiers/sailors who reside in a correctional institution with crucial quality of service, the diminishment of their freedom spreads from solely military matters to other parts of life such as meals, visiting and visitor hours, as they were separated from parents, members of the family, and quasi peers the rest of the time. Cole (2000) According to the research, the adaptability of barrack lodging to the demands of soldiers/sailors is critical for housing initiatives to be judged with good service quality and success. He went on to say that a barrack with good service is a safe haven for soldiers and sailors during their time in the barracks. Non-residential troops who pay anything, no matter how petty, for traveling to and from workplace likely to save more revenue than crematorium soldiers.

\subsection{Military Housing Adequacy}

Individuals choose to use a housing environment that allows them to optimize the fulfillment of particular attributes associated with their houses and home surroundings. However, in a society where options and resources are limited, it appears that the "pleasure" people connect with components of their dwelling situation is critical. Housing contentment and pleasure are frequently viewed as an entity containing a large number of accommodation units showing qualities such as physical quality of necessary services, service standard, and neighborhood characteristics. Components of fundamental quality of service span sturdiness, effective space and facility planning to ensure appropriate security, and cognitive happiness in the use of spaces and facilities. The classification of such characteristics should serve as a reference for deciding on measures appropriate to the relative habitability of soldiers'/sailors' barracks. According to research, characteristics such as family structure and shape, stage in the life phase, income, education level, age, and the number of babies all impact people's contentment with dwelling. Based on the preceding review, this study examined the impact of living condition supplied, sufficiency, and choice for dwellings given. 


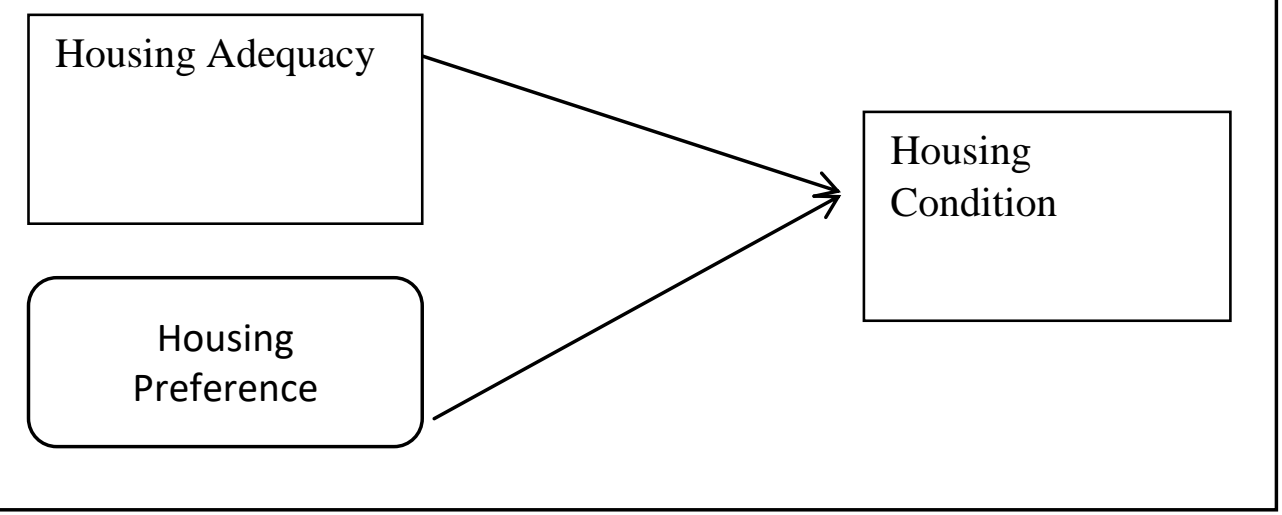

Figure 1: Conceptual Framework

\section{III.METHODOLOGY}

The research approach used is quantitative. A questionnaire was created and distributed to the responders. The population of this research is military troops at Shadawanka Barrack Bauchi. Because military personnel are in the greatest position to respond to the living circumstances they require, random sample procedures were used. This strategy was chosen because it enabled the use of statistical procedures for interpreting sample findings, such as calculating a confidence interval around the sample mean. This gave a representative sample sample from the population the potential to extrapolate to the entire population (Polit, \& Beck, 2010). Purposive and random sampling was also chosen since it is one of the simplest and quickest methods of picking a sample (Keyton, 2014). The example frame consists of 248 dwellings, each with one personnel. Krejcie and Morgan's table was used to calculate the sample size (1970). Referring to table, a sample size of 148 was chosen, while a sample size of 160 was used for distribution to ensure appropriate replies. Following extensive data collecting, the type of data analysis used to analyze the data collected from the field were descriptive, mean ranking, and multiple linear regression using SPSS Version 22.

\subsection{The Study Area}

The study takes place in Bauchi, one of Nigeria's geopolitical states. The research is focused on the Bauchi Metropolitan Area in particular. As a result, Shadawanka barrack is part of the Bauchi Metropolitan Area, which is part of Bauchi State. The state is now in Nigeria's north-eastern region, with Bauchi as its capital. It was founded in 1976 and today comprises 20 Local Government Areas, the capital of which is Bauchi LGA. Bauchi Metropolis was chosen as the research region since it is the state capital and has a greater population and literacy rate among people. As a result, the neighborhood has municipal infrastructures, as well as social, political, and educational services including motorways and road
Presentation and Discussion of Results

Table 1 Dissemination of questionnaire

Table 1: Questionnaire administration

\begin{tabular}{|c|c|c|c|}
\hline Blocks & $\begin{array}{c}\text { Questionnaire } \\
\text { Administered } \\
\text { (Sample Size) }\end{array}$ & $\begin{array}{c}\text { Questionnaire } \\
\text { Collected }\end{array}$ & $\begin{array}{c}\text { Questionnaire } \\
\text { Analysed }\end{array}$ \\
\hline TOTAL & 160 & 158 & 150 \\
\hline
\end{tabular}

\section{RELIABILITY OF THE SURVEY QUESTIONNAIRE}

Cronbach's alpha was used to determine the reliability of the field questionnaire survey, as proposed by Pallant (2011). The questionnaire's aggregate Cronbach's alpha was.958. This indicates that the entire questionnaire is trustworthy and appropriate. Table 2 shows the results of the field survey's reliability test. Cronbach's alphas for each of the constructions are all within reasonable parameters (Pallant, 2011).

Table 2: Cronbach's alpha

\begin{tabular}{|c|c|c|c|}
\hline S/N & Constructs & $\begin{array}{c}\text { Cronbach's } \\
\text { alpha }\end{array}$ & Items \\
\hline 1 & All questionnaire & .958 & 57 \\
\hline 2 & Housing Condition & .904 & 13 \\
\hline 3 & $\begin{array}{c}\text { Adequacy of } \\
\text { Housing }\end{array}$ & .861 & 12 \\
\hline 4 & Preferred Housing & .934 & 16 \\
\hline
\end{tabular}

\subsection{Demographic attribute}

Table 3: Level of occupation

\begin{tabular}{|c|c|c|c|c|}
\hline & & Items & $\begin{array}{c}\text { Freque } \\
\text { ncy }\end{array}$ & Percent \\
\hline \multirow{4}{*}{1} & $\begin{array}{c}\text { Number of } \\
\text { Soldiers staying } \\
\text { in your house? }\end{array}$ & 1 soldier & 34 & 22.7 \\
\cline { 3 - 5 } & 2 soldiers & 54 & 36.0 \\
\cline { 3 - 5 } & $\begin{array}{c}\text { More than } 3 \\
\text { soldiers }\end{array}$ & 12 & 30.3 \\
\hline
\end{tabular}




\section{Volume X, Issue XII, December 2021|ISSN 2278-2540}

Table 3: Shows the findings of the number of troops residing in a residence, with the Shadawanka Barrack having the highest rate of 36 percent. Furthermore, in the research region, more than three troops residing in the residence account for the lowest number of 8.0 percent. This suggests that the majority of the residences in the study region were occupied by two troops.

\subsection{The Conditions of Houses Provided in Shadawanka Barrack, Bauchi State}

To examine the degree of conditions of residences given in Shadawanka Barrack, Bauchi State, descriptive statistical analysis predicated on mean ranking were used. The ranking, mean, and standard deviation for every Items were shown in Table 2.

Table 4 shows the condition of the residences in Shadawanka Barracks.

\begin{tabular}{|c|c|c|c|c|}
\hline Variable & Mean & $\begin{array}{c}\text { Std. } \\
\text { Deviation }\end{array}$ & Rank & $\begin{array}{c}\text { Remark } \\
\text { s }\end{array}$ \\
\hline Security & 3.2953 & 1.20682 & 1 & Fair \\
\hline Wall & 3.1879 & 1.09526 & 2 & Fair \\
\hline Floor & 3.1170 & 1.0200 & 3 & Fair \\
\hline Finishing & 3.1014 & 1.04104 & 4 & Fair \\
\hline $\begin{array}{c}\text { Fire Protection } \\
\text { equipment }\end{array}$ & 3.0878 & 1.19242 & 5 & Fair \\
\hline Ceiling & 3.0811 & 1.16154 & 6 & Fair \\
\hline Doors/windows & 3.0747 & 1.01070 & 7 & Fair \\
\hline Water Supply & 3.0408 & 1.04835 & 8 & Fair \\
\hline Solid Waste Disposal & 2.9530 & 1.01224 & 9 & Low \\
\hline Parking lot & 2.9463 & 1.04775 & 10 & Low \\
\hline Drainage & 2.9329 & 1.08476 & 11 & Low \\
\hline Sewerage & 2.8851 & 1.07143 & 12 & Low \\
\hline Road Networks & 2.8176 & 1.00360 & 13 & Low \\
\hline $\begin{array}{c}\text { Total mean condition } \\
\text { of houses }\end{array}$ & 3.0372 & .76955 & & Fair \\
\hline
\end{tabular}

Table 4 depicts the state of the houses in the Shadawanka barrack. The variables with reasonable conditions are security, which had the highest mean value of $(\mathrm{M}=3.2953$, std. deviation $=1.20682$ ) ranked first, wall condition, which had the second highest mean value of $(\mathrm{M}=3.1879$, std. deviation $=1.20682$ ) ranked second, floor condition, which had the third highest mean value of $(\mathrm{M}=3.117$, std. deviation = 1.0200), finishing, which had the fourth highest mean value of $(\mathrm{M}=3.10$ Sewerage and electricity are the least desirable dwelling conditions in Shadawanka barrack. The ceiling condition is also represented by the mean value of $(\mathrm{M}=$ $3.0811, \mathrm{SD}=1.16154)$, which is placed fifth. Sewerage and electricity are the least desirable dwelling qualities in Shadawanka barrack.

\subsection{The Adequacy of Houses Provided in the Study Area}

To analyze the degree of suitability of dwellings given in Shadawanka Barrack, Bauchi State, descriptive statistics based on mean ranking were used. Table 3 displayed the ranking, mean, and standard deviation for each Item.

Table 5: Adequacy of houses provided

\begin{tabular}{|c|c|c|c|c|}
\hline Adequacy of houses & Mean & $\begin{array}{c}\text { Std. } \\
\text { Deviation }\end{array}$ & $\begin{array}{c}\text { Ra } \\
\text { nki } \\
\mathrm{ng}\end{array}$ & Remarks \\
\hline Water Supply & 3.4122 & 1.18111 & 1 & Moderate \\
\hline Security & 3.3871 & 1.15011 & 2 & Moderate \\
\hline Sewerage & 3.2271 & 1.26290 & 3 & Moderate \\
\hline Fire Protectionequipment & 3.1837 & 1.14118 & 4 & Moderate \\
\hline Solid Waste Disposal & 3.1099 & 1.08159 & 5 & Moderate \\
\hline Number of Sitting Room & 2.9597 & 1.10447 & 6 & inadequate \\
\hline Number of Kitchen & 2.9396 & 1.06958 & 7 & inadequate \\
\hline Number of Toilet/Bath & 2.9262 & 1.01064 & 8 & inadequate \\
\hline Number of Bedrooms & 2.9208 & 1.15588 & 9 & inadequate \\
\hline Parking lot & 2.8926 & 1.13599 & 10 & inadequate \\
\hline Drainage & 2.8784 & 1.12271 & 11 & inadequate \\
\hline Road Networks & 2.7584 & 1.06595 & 12 & Inadequate \\
\hline Total level adequacy & 2.8965 & .88537 & & Inadequate \\
\hline
\end{tabular}

Table 5 displays the findings of adequacy for the dwellings given in Shadawankabarrack. Water supply, with the highest mean value of $(\mathrm{M}=3.4122$, standard deviation $=1.18111)$, ranked first, followed by security $(\mathrm{M}=3.3871$, standard deviation $=1.15011)$, sewerage $(\mathrm{M}=3.2271$, standard deviation $=1.26290)$ ranked third, fire protection $(\mathrm{M}=$ 3.1837 , standard deviation $=1.14118$ ) ranked fourth, and solid waste disposal $(\mathrm{M}=3.1837$, standard deviation $=1.14118)$ ranked fifth. Parking lot with a mean value of $(\mathrm{M}=2.8926$, standard deviation $=1.13599)$ ranked 10th, trailed by drainage with a mean value of $(\mathrm{M}=2.8784$, standard deviation $=$ 1.12271) ranked 11th, and transport systems with a mean value of $(M=2.7584$, standard deviation $=1.06595)$ ranked 12th. The general degree of appropriateness of the barracks' housing was rated unsatisfactory $(\mathrm{M}=2.8965$, standard deviation $=.88537$ ).

\subsection{The Preferred Housing by Military Personnel in the Study Area}

In Shadawanka Barrack, Bauchi State, descriptive statistics based on mean ranking were used to analyze military personnel's preferred lodging. The ranking, mean, and standard deviation for each Item were shown in Table 5.

Table 6: Military personnel's preferred housing facilities

\begin{tabular}{|c|c|c|c|c|}
\hline preferred housing & Mean & $\begin{array}{c}\text { Std. } \\
\text { Deviation }\end{array}$ & $\begin{array}{c}\text { Rankin } \\
\mathrm{g}\end{array}$ & Remarks \\
\hline Water Supply & 3.9247 & 1.20450 & 1 & Moderate \\
\hline Quality of Floor & 3.8707 & 1.13994 & 2 & Moderate \\
\hline $\begin{array}{c}\text { Number of } \\
\text { Bedroom }\end{array}$ & 3.8639 & 1.14481 & 3 & Moderate \\
\hline Quality of Roof & 3.8558 & 1.20102 & 4 & Moderate \\
\hline
\end{tabular}




\begin{tabular}{|c|c|c|c|c|}
\hline $\begin{array}{c}\text { Fire Protection } \\
\text { equipment }\end{array}$ & 3.8503 & 1.27102 & 5 & Moderate \\
\hline Drainage & 3.8499 & 1.17213 & 6 & Moderate \\
\hline Quality of Ceiling & 3.8311 & 1.12559 & 7 & Moderate \\
\hline Quality of Wall & 3.8163 & 1.25329 & 8 & Moderate \\
\hline Security & 3.8027 & 1.34434 & 9 & Moderate \\
\hline $\begin{array}{c}\text { Number of Sitting } \\
\text { Room }\end{array}$ & 3.7891 & 1.10661 & 10 & Moderate \\
\hline Parking lot & 3.7619 & 1.20588 & 11 & Moderate \\
\hline $\begin{array}{c}\text { Number of } \\
\text { Toilet/Bath }\end{array}$ & 3.7397 & 1.14138 & 12 & Moderate \\
\hline $\begin{array}{c}\text { Number of } \\
\text { Kitchen }\end{array}$ & 3.7347 & 1.14883 & 13 & Moderate \\
\hline Road Networks & 3.7005 & 1.17798 & 14 & Moderate \\
\hline $\begin{array}{c}\text { Solid Waste } \\
\text { Disposal }\end{array}$ & 3.6327 & 1.20448 & 15 & Moderate \\
\hline Sewerage & 3.4626 & 1.22212 & 16 & Moderate \\
\hline $\begin{array}{c}\text { Adequacy of } \\
\text { housing }\end{array}$ & 3.7686 & .91631 & & Moderate \\
\hline
\end{tabular}

Table 6 depicts military personnel's preferred lodging at Shadawanka barrack Bauchi. Water supply is ranked first with a mean of $(\mathrm{M}=3.9247$, std. deviation $=1.20450)$, followed by quality of floor with a mean of $(\mathrm{M}=3.8707$, std. deviation = 1.13994), number of bedrooms with a mean of $(\mathrm{M}=3.8639$, std. deviation $=1.14481)$, quality of roof with a mean of $(\mathrm{M}=$ 3.8558 , std. deviation $=1.20102)$, and fire protection with mean of $(\mathrm{M}=3.8503$, std. deviation $=1.27102)$ ranked at fifth. Road networks, waste disposal, and sewage system are the least desired housing, but have a moderate level of adequacy, with mean and standard deviations of $(\mathrm{M}=3.7005$, std. deviation $=1.17798),(\mathrm{M}=3.6327$, std. deviation = 1.20448), and $(\mathrm{M}=3.4626$, std. deviation $=1.22212)$ ranked 14 th to 16th, respectively. The overall appropriateness of housing is modest $(\mathrm{M}=3.7686$, standard deviation $=.91631)$.

4.5 Effect of Housing Condition Provided on Preferred Housing for Military Personnel and Adequacy of Houses Provided

\begin{tabular}{|c|c|c|c|c|c|c|c|c|c|c|}
\hline & \multirow{2}{*}{ Model } & \multicolumn{2}{|c|}{$\begin{array}{l}\text { Unstandardized } \\
\text { Coefficients }\end{array}$} & \multirow{2}{*}{$\begin{array}{c}\text { Standardized } \\
\text { Coefficients } \\
\text { Beta } \\
\end{array}$} & \multirow{2}{*}{$\mathrm{t}$} & \multirow{2}{*}{ Sig. } & \multicolumn{2}{|c|}{$\begin{array}{l}95.0 \% \text { Confidence Interval } \\
\text { for B } \\
\end{array}$} & \multicolumn{2}{|c|}{ Collinearity Statistics } \\
\hline & & B & $\begin{array}{l}\text { Std. } \\
\text { Error }\end{array}$ & & & & $\begin{array}{l}\text { Lower } \\
\text { Bound }\end{array}$ & Upper Bound & Tolerance & VIF \\
\hline \multirow{4}{*}{1} & (Constant) & .730 & .231 & & 3.157 & .002 & .273 & 1.188 & & \\
\hline & Conditions & .260 & .074 & .272 & 3.505 & .001 & .113 & .406 & .657 & 1.521 \\
\hline & Adequacy & .229 & .056 & .285 & 4.082 & .000 & .118 & .339 & .812 & 1.232 \\
\hline & Preference & .219 & .065 & .264 & 3.383 & .001 & .091 & .347 & .649 & 1.540 \\
\hline
\end{tabular}

a. Dependent Variable: Condition

The comparison of standardized expected values to standardized residuals revealed that the data matched the assumption of variance homogeneity and that the residuals were nearly normally distributed. As a result, the beta coefficient demonstrates that housing condition, desired housing for military people, and appropriateness of homes given are important drivers of satisfaction with houses provided, as evidenced by significant $\mathrm{P}$-values at $0.001,0.001$, and 0.000 significance levels. The standardized beta coefficient for adequacy of the dwellings that showed unsatisfactory level in descriptive analysis is 0.285 .

\section{DISCUSSION OF FINDINGS}

According to the results from Akoh, Kibon, Abbas, and Daukere (2020), over 91 percent of the residential units in Sobi Barrack were one-room and parlour apartment, while two-bedroom apartments and one-bedroom flats represented for just 5.05 percent and 1.34 percent, respectively. In contrast to the conclusions of this study, Abdu, Bichi, Umar, and Nadikko (2019) found that 81 percent of respondents considered the barracks were not safe since there was no accessible fence. In contrast to the findings of this study on water for household use, Abdu, Bichi, Umar, and Nadikko (2019) found that 58.2 percent of respondents rely on water sellers, 30.4 percent on commercial water tankers, and the remainder respondents rely on alternative water sources. The status of housing units and other amenities in the study region was also investigated by Akoh, Kibon, Abbas, and Daukere (2020). According to the results of the investigation, 19.72 percent of the dwellings had bad roofs, while just 13.48 percent had decent roofs. According to Abdu, Bichi, Umar, and Nadikko (2019), 72.2 percent of respondents discard their trash in specified disposal places, whereas $27.8 \%$ burn it.

\section{VI.CONCLUSION}

In Shadawanka Barrack Bauchi, the research evaluates military housing provision and troops' housing preferences. The barrack's dwelling conditions were rated fair on a scale of one to ten. Water supply and security have high levels of adequacy, whereas sewerage and transportation networks are the least decent housing factors with low levels of responsiveness. The overall degree of appropriateness of the barracks' housing was deemed insufficient. Water supply, flooring condition, and bedroom count are the most chosen housing factors, whereas road systems, disposal of waste, and sewage are the least liked housing elements. 


\section{RECOMMENDATIONS}

The sewage and solid disposal of wastes must be improved. The service might be contracted out to a privately owned company. Inside the barrack, the interior major roads and sewage system should be maintained, and new units can be built to offer proper connectivity. There is a need for extra housing to alleviate the overcrowding across most homes.

\section{REFERENCES}

[1] Abdu, A., Bichi, A. M., Umar, Y. A., \& Nadikko, B. J. (2019). An assessment of housing satisfaction in police barracks of Gombe State, Nigeria, International Journal of Recent Scientific Research, 10, (04A), 31647-31654.

[2] Alabi, O., Kayode, S., Misbahu, A., \& Olaifa, O. (2021). Effect of Physical Characteristics on Resident's Satisfaction in a HighDensity Area of Ilorin Metropolis. Path of Science, 7(9), 10011006. doi:http://dx.doi.org/10.22178/pos-74.1

[3] Akoh, H. O., Kibon, A. U., Abbas, S., \&Daukere, B. E. (2020), Developing geo-database for housing and facilities management in Sobi Barracks Ilorin, Kwara state, Nigeria, Sahel Journal of Geography, Environment and Development, 1(1), 117-129.

[4] Akomolede, K. (2007) Low Income Earners and the Burden of Home Ownership in Nigeria, Nigerian Guardian Newspaper of January, 29; p. 29.

[5] Al-Habees, M. A. (2012). Determination of the Residential Housing Needs Expected for Cities of Jordan Within the Period of 2014-2024, Management Science and Engineering, 6(2): 130-139.

[6] Cohen, E. A. (2017). The big stick: the limits of soft power and the necessity of military force. Hachette UK.

[7] Cole, K. A. (2000). Prioritizing Quality of Life Issues: Laying a Vision for Tomorrow (Joint Vision 2010). Air Command And Staff Coll Maxwell Afb Al
[8] Kayode, S. J., Muhammad, M. S., \& Bello, M. U. (2021). Effect of Socio-Economic Characteristics of Households on Housing Condition in Bauchi Metropolis, Bauchi State, Nigeria. Traektoria Nauki $=$ Path of Science, 7(7), 2001-2013

[9] Kelly, S. M. T. (2020). Suicide in the Barracks: Architecture and Social Connection in Military Housing (Doctoral dissertation, University of Oregon).

[10] Krejcie, R.V. \& Morgan, D. W. (1970). Determine sample size for research activities. Education Psychology Measures, 30(3).

[11] Kurraz, H. A. and Ziara, M. (2007). Towards Lowering the Cost of Houses in Palestine: New Perspective. The Islamic University Journal (Series of Natural Studies and Engineering), 15(2): 1-12.

[12] Musa, H. A., Bello, M. U., \& Kayode, S. J. (2021). Effect of Neighbourhood Characteristics on Resident's Satisfaction in Doya Area of Bauchi Metropolis. Traektoriâ Nauki= Path of Science, 7(4), 6001-6005.

[13] Pallant, J. (2011). SPSS Manual, a step by step guide to data analysis using SPSS. (4th ed.), Berskhire: Open University Press.

[14] Polit, D. F., \& Beck, C. T. (2010). Generalization in quantitative and qualitative research: Myths and strategies. International journal of nursing studies, 47(11), 1451-1458.

[15] Sakariyau, J. K., Uwaezuoke, N. I,, Olaoye, T K.,\& Sani, G.S (2021). Housing affordability among civil servants in Ekiti state, Nigeria. International Journal of Research and Review. 2021; 8(10): 383-390. DOI: https://doi.org/10. 52403/ijrr.20211051

[16] Sean, S. L., \& Hong, T. T. (2014). Factors affecting the purchase decision of investors in the residential property market in Malaysia. Journal of Surveying, Construction and Property, 5(2), $1-13$.

[17] UN Shelter Sector. (2011). Assessing Housing Needs in Gaza, June 2007-December 2011. 